UDC $\quad 669.162 .275 .2: 669.054 .82$

特別講演

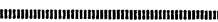

\title{
高炉スラグの 骨材その他コンクリート材料への適用*
}

\author{
國分正 胤** \\ Application of Blast-furnace Slag as Aggregate \\ and Other Materials for Concrete
}

Masatane KoKuBU

\section{1. 序}

栄えある浅田賞を授与されましたことは，私の身に余 る栄誉であります．この数年コンクリート研究者のグル ープはスラグの活用について活発な調査研究を続けてお り，その成果は貴重な資料となつております。

今回の栄誉は，これらの研究に対するものであり，私 がその代表者といらことで授与されたものとも言えるの でありまして，まず御研究いただいた各位に深甚な敬意 を表する次第であります.

我が国の高炉スラグは，その一部は古くから高炉セメ ントの材料として使用されてきたが，数年以前までは大 部分の用途は埋立て材料・路盤材料等であつた. しかし その後環境保全の厳しい条件により海岸の埋立ては著し く制限され，な打省資源の気運の高揚とも相まつて，こ れをコンクリート骨材として利用するよらになつたので ある. 我が国に拈ける高炉スラグの生産量は膨大で，年 間 3000 万 $\mathrm{t}$ 以上にも達しているので, これが省資源及 び省エネルギの観点から注目を浴び始めたのは当然であ る.

当時高炉スラグは一般に徐冷処理していたので，最初 の検討はこの徐冷スラグを所定の粒度に破砕してコンク リート粗骨材を製造することに重点が指向された． 約 2 年前から高炉スラグを水で急冷した水砕スラグを用い て，細骨材を製造することが研究され始めたのである.

省エネルギの見地から，高炬スラグをセメントやコン クリートの混和材として活用することにも関心を寄せた 研究者があり，それぞれ研究を進めてきた．土木学会で も昭和 51 年学術講演会における研究討論会の主題の一 つに“高炉スラグのコンクリート材料としての利用”を 選定し，500 人を超える技術者が一堂に会して活発な論 議を展開したこともある1).

この報告は，高炉スラグをコンクリート骨材として用 いるための調査研究について述べると共に，その場合の
問題点について論じ，更にセメント・コンクリート用混 和材としてのスラグの価值について論じたものである.

\section{2. 高炉スラグのコンクリート粗骨材 への適用}

昭和 49 年 9 月に, 建材試験センターは, 日本鉄鋼連 盟から“高炉スラグの試験並びにスラグ粗骨材 JIS 及び スラグ䂠石コンクリート設計施工指針の原案作成”につ いての研究を委託された。これを受けて土木・建築・鉄 鋼の 3 分野の研究者より成り浜田稔東大名誉教授及び筆 者を研究委員長とするコンクリート用高炉スラグ骨材標 準化研究委員会が組織され, 大規模な調查研究が開始さ れた，骨材資源がそしくなりつつある現状からみても誠 に時宜を得たものと言える. 浜田名誉教授は残念にも昭 和 49 年 12 月に逝去されたので，その後は岸谷孝一東 大教授が研究委員長を代行した.

前記の研究委員会には骨材とコンクリートの 2 部会を 設け，骨材部会は部会長に岸谷東大教授・副部会長に西 沢紀昭中央大教授が就任しコンクリート用高炉スラグ粗 骨材 JIS 原案の作成を担当し，コンクリート部会は部 会長に樋口芳朗東大教授・副部会長に上村克郎博士が就 任し高炉スラグ砕石コンクリート設計施工指針案の作成 を担当した. この JIS 原案に基づき，昭和 52 年に JIS A 5011 コンクリート用高炉スラグ粗骨材が制定された. またこの設計施工指針案に基づいて，土木学会及び日本 建築学会においてそれぞれ検討を重ね，両学会の高炉ス ラグ砕石コンクリート設計施工指針 (案) が制定され2), 高炉スラグ粗骨材を広く活用するための基準がととのつ たのである。

JIS A 5011 においてはまず高炉スラグ粗骨材の鉱物 学的安定の確保を考慮して酸化カルシウム $(\mathrm{CaO}$ とし て)及び全鉄 $(\mathrm{FeO}$ として)の含有量を制限すると共に， スラグ粗骨材を用いたコンクリートの化学的不安定及び 鉄筋の腐食を誘起する抢それを消隇させるため，三酸化

* 昭和 54 年 10 月 16 日 本会講演大会における浅田賞受賞記念特別講演

** 武蔵工業大学工学部教授 工博 (Musashi Institute of Technology, 1 Tamazutsumi Setagaya-ku 158) 
硫黄 $\left(\mathrm{SO}_{3}\right.$ として) 及び全硫黄 $(\mathrm{S}$ として $)$ の含有限度を規 定した.

溶融スラグには溶存ガスが含まれていると共に，冷却 時にガスが発生する．スラグが凝固する過程で，これら のガスが内部に閉じ込められるので，徐冷スラグはある 程度の気孔を含有することになり，これによつて強度・ 水密性・耐久性等が低下する. 畑方式により特に薄層々 して流し込及(薄層多層流し方式という)泠却すれば，緻 密で強い材質のものが得られる。このように，冷却方式 によつて品質が相違するので, JIS では絶乾比重・吸水 率・単位容積質量等により高炉スラグを $\mathrm{A}$ 種及び $\mathrm{B}$ 種 （良質のものである）に分類している．我が国の代表的製 鉄所で生産される高炉スラグ粗骨材はほとんどすべてが $\mathrm{B}$ 種である3)。高炉スラグ砕石コンクリート設計施工指 針の解説には, 多くの実験を集録した結果から，B 種粗骨 材を用いたコンクリートの強度・耐久性・水密性等は, 通常の挽石を用いた同一水セメント比のコンクリートと 大差無いと述べてある2).

水セメント比及びスランプを一定に保つて試験した場 合に括ける，3 工場産 B 種スラグ粗骨材を用いたコンク リートの強度を河川産砂利コンクリートの場合と比較し た一例は，図 1 のようである4). 3 種のスラグ粗骨材の 粒の強さは砂利粒に 比べて 相当に弱く，曲げ試験の破 断面ではほとんどすべてのスラグ粗骨材粒が破断してい た.しかしこれらを用いたコンクリートの強度は砂利を 用いた場合より強くなつている。 これはスラグ 粗骨材 粒の表面が粗であるためにモルタルとの付着性能が向上 し，これが粒自身の弱いことの悪影響を補つたことによ ると思われる.

高炉スラグ粗骨材は，相当に良好の粒形に破砕したと しても粒は角張つて拉り，表面は砂利よりもはるかに粗 であつて凸凹を有している，従つてこれを用いると，作
業に適するワーカビリチーのコンクリートを得るに必要 な単位水量は，一般の砕石を用いる場合と比較すれば同 程度であるが河川産砂利を用いる場合よりは増加する。 その増加量は, 粗骨材の最大寸法 $20 \mathrm{~mm}$ の場合でスラ グ粗骨材の実積率が $60 \%$ 程度であれば，約 $6 \%$ であ る2)。それで高炉スラグ粗骨材ュンクリートは，適当な 空気量をもつ $\mathrm{AE}$ コンクリートとすることを規定したの である. AE コンクリートとすれば, コンクリートのワ 一カビリチーは格段に向上し単位水量は減ずる.

高炬スラグ粗骨材がコンクリートの耐久性に及ぼす影 響を細部にわたつて解明することは極めて困難である. それは，それらの影響が，スラグ粗骨材の化学組成・粒 の表面性状及び強さ並びに空隙・コンクリートの配合. コンクリートの養生状態並びに材令等によつて異なるば かりでなく，コンクリートの耐久性の試験方法が確立さ れていないからである. 高炬スラグ粗骨材の耐久性につ いての資料を得るため，コンクリート用高炉スラグ骨材 標準化研究委員会は，日本の全国にわたつてこれを使用 したコンクリートの工事例を 35 例収録し，その主要な ものにつきコアボーリングその他によつてコンクリート の現状を調査した ${ }^{3)}$. これらの例は, 海中又は海岸のも のが多く, コンクリート量は大半が $75000 \sim 600 \mathrm{~m}^{3}$ の範 囲に相違しているが，200000 $\mathrm{m}^{3}$ 及び $160000 \mathrm{~m}^{3}$ のも のが各 1 例ずつある.コア供試体の圧縮強度試験結果は いずれも所期の強度以上であり，コンクリートの中性化 深さも小さく, 劣化の著しいものや変状が認められたも のは全く発見されなかつた. 経過年数が 5 年以内の例 が $1 / 3$ を占めているので, 断定的な結論を下すことはで きないが，これらの調査例は，入念に施工すれば，高炉 スラグ粗骨材を用いても所要の耐久性を持つュンクリー トを造り得ることを示すものと思われる.
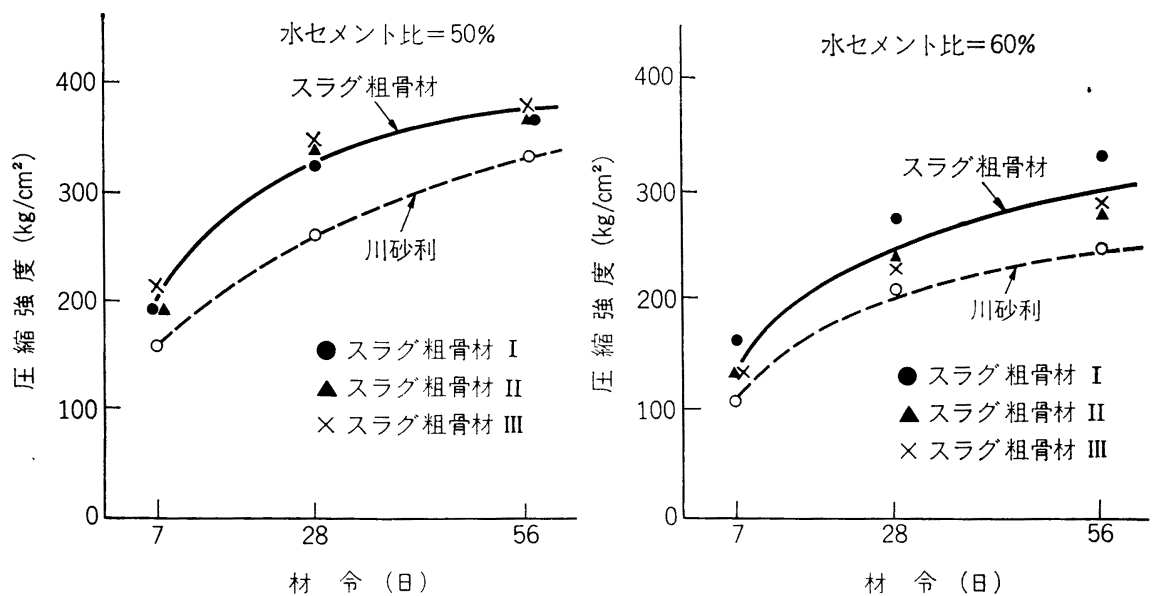

図 13 種の高炉スラグ粗骨材並びに河川産砂利を用いたコンクリートの 圧縮強度 $\left(21^{\circ} \mathrm{C}\right.$ の水中養生) 


\section{3. 高炉スラグ細骨材の JIS 原案並びにこ れを用いるコンクリートの施工基準}

建材試験センターに設置された前記の研究委員会は, 高炉スラグ粗骨材に関する調査研究を進めている間に, 長滝重義東工大助教授を主査とする高炉スラグ細骨材研 究グループをも組織して細骨材の調査研究を開始した. その後この研究グループは細骨材研究小委員会に再編成 された. この研究小委員会は, 小林正几法大教授を主査 として調査・実験及び 現場試験を重ねた結果，昭和 52 年 3 月にコンクリート用高炉スラグ砕砂 JIS 原案5) 並び に高炉スラグ砕砂コンクリート施工マニュアル案を作成 した. 高炉スラグ砕砂 JIS 原案は, 溶融高炉スラグを急 冷したものを破砕し適当な粒度となるように調整したも のを対象としており，徐冷スラグは対象としていない. また絶乾比重及び吸水率の規定值は, それぞれ 2.5 以上 及び $2.5 \%$ 以下であつて, 粗骨材の場合より撖しく定め てある。

細骨材研究小委員会が実施した実験の一例を示せば次 のようである. 吸水率が $1.65 \%$ 及び $3.69 \%$ の 2 種の 急冷砕砂並びに $4.17 \%$ 及び $6.18 \%$ の 2 種の徐冷研砂 を用いた場合について，それぞれ 3 種の水セメント比 $(45 \% \cdot 55 \%$ 及び $65 \%)$ でスランプ約 $8 \mathrm{~cm}$ のコンクリ ートの強度を試験し, 川砂を用いた場合の強度と比較し た結果によれば，吸水率 $1.65 \%$ の急冷砕砂を用いたコ ンクリートの材令 7 日・28 日及び 91 日に打ける圧縮 強度は，川砂を用いた場合の強度の 93〜 125\%であつた が，吸水率 $3.69 \%$ の急冷砕砂を用いた場合は 86〜102 \%であり, 吸水率 $4.17 \%$ の徐冷砕砂を用いた場合は, 川砂の場合の 81 94\% であり, $6.18 \%$ を用いた場合は 65〜82\% であつた6). なお $\mathrm{AE}$ コンクリートについて 凍結融解試験を行つて耐久性を比較した結果, 吸水率が $2 \%$ 程度以下の砕砂を用いた場合の耐久性指数は良質な 川砂を用いた場合のものと拈括むね同等であるが，吸水 率の大きいものを用いるほど耐久性は低下することが示 された.

前記のような実験結果を参照し，スラグ砕砂 JIS 原案 に拈いては, 絶乾比重及び吸水率の規定值を定めたので ある.な捈冷スラグを対象としなかつたのは，これを 用いたコンクリートの強度・耐久性等が劣ること, 徐冷 スラグの場合には品質のばらつきが大きくなることが認 められたこと，等によるものである.

しかし急冷スラグ砕砂についての調査研究を実施中 に，この種砕砂を戸外に推積して扝くと固結する場合の あることが認められた. これは急冷スラグ砕砂の実用上 の問題点でもあるので, これに対する解決策が明らかに されない限り JIS 制定は見合わせることとし，一層の研 究を継続することにした.

その後日本鉄鋼連盟は，昭和 52 年度建設省建設技術
研究補助金を受け，岸谷東大教授を委員長として水砕ス ラグ細骨材の使用基準の研究委員会を設置して活発な研 究を行い，昭和 53 年 3 月にその成果を報告した7).

昭和 51 年 54 年にかけて, 各製鉄所はそれぞれ水砕 スラグ細骨材の製造施設を整備し試験を行つて検討を重 ね, 更に各工場のコンクリートに水砕スラグ細骨材を試 用した施工実績も 15 万 $\mathrm{m}^{3}$ に達し各工場の製品は逐次 向上したのである.な打水砕スラグだけでなく，高炉ス ラグ粒を空中に浮遊させ冷却して製造した風砕スラグ細 骨材も新たに開発された。

この現状にかんがみ，日本鉄鋼連盟は昭和 54 年 6 月 にコンクリート用高炉スラグ細骨材標準化研究委員会を 組織して大規模な調査研究に着手した.この委員会は, 全国の代表的なコンクリート研究者を網羅したもので委 員総数は 88 名に達し, 筆者が委員長を大島久次千葉工 大教授が副委員長を勤め, 樋口東大教授及び岸谷東大教 授が委員長補佐に当たつている. 短期間に所期の成果を 挙げるため, 調査研究の重点をコンクリート工場製品に 指向した. すなわち代表的な工場製品として生コンクリ ート・高強度コンクリート・コンクリート製品・土木積 ブロック・左官用砂・等を選び，これらに応じて 5 種の 部会を設置した. この委員会は, 高炉スラグ細骨材を使 用する場合の各種問題点の解明に努めまた高炉スラグ細 骨材 JIS 原案を作成しょうとするものである.

\section{4. 高炉スラグ細骨材における問題点}

（1）高炬スラグ細骨材の固結について

徐冷スラグは結晶質で水硬性は全く持たないが，急冷 高炉スラグはガラス質より成り，これを粉砕したものは 潜在水硬性を有している. 潜在水硬性とは，それ自身で は硬化しないがセメントの水和によつて生ずる水酸化カ ルシウムその他アルカリ塩類と反応して水和物を生成し 硬化する性質である. 急冷高炉スラグ細骨材を長期間戸 外に堆積しておくと, 固まることがある.これは微量の 塩類が微粉末スラグに及ぼす影響で, 硬化といら程では なく粒子が相互に膠着して固結を生ずるのである. しか し軽度の固結であつても，この現象によつて高炉スラグ 細骨材の取り扱いに困難を生ずることがある.

日本鉄鋼連盟ではこの固結について大規模な試験研究 を実施しているが，現在までに，(i) 高炉スラグの塩基度 の高い程, 微粉分の多い程また細骨材の締固め度が高い 程固結が著しくなること，(ii) 冬季には起こらないこ と, (iii) 夏季にのみ発生するが梅雨後の盛夏には約 2 週 間の堆積でも固結すること, 等が明らかにされている. 乾燥した細骨材で発生しないのは当然である.な特固結 を防ぐ手段としては，(i) 天然砂を約 $25 \%$ 以上混合し て堆積すること, (ii) 堆積期間をなるべく短くするこ と, 等を挙げている ${ }^{8)}$. 細骨材標準化研究委員会は, 固 結の試験方法並びに実用的な防止方法について検討を重 
ねる予定である。

(2) 高炉スラグ細骨材の粒度の均等性について

コンクリートの製造に扔いて最も重要な項目は均等性 の確保であるが，均等なコンクリートを造るための第一 の条件は, 用いる骨材特に細骨材の粒度の均等性である. 骨材の粒度を均等に保つためには, 粒径応じてらるい 分けて別々に貯蔵し, 使用時に各粒径のものを所定の割 合す゚つ計り取つてミキサへ投入する。重要な工事ほど粒 径別の区分を多くして粒度の均等性を向上させるのであ る.これは，大小粒が混合した状態で骨材を運搬したり 集積したりすると, 取り扱い中に分離して大粒と小粒に 分かれてしまい粒度が变化するからである。

写真 1 はレデーミクストコンクリート工場に拈ける骨

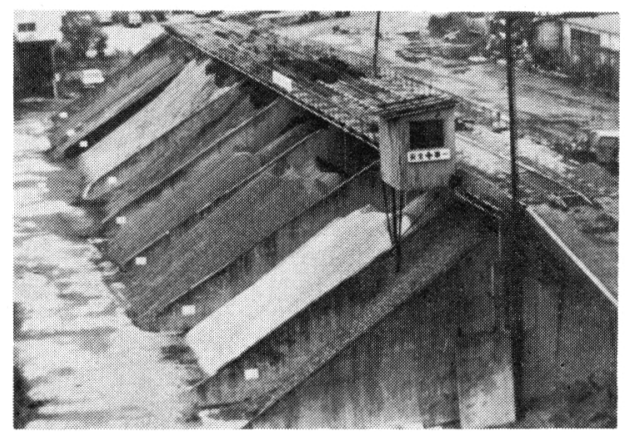

写真 1 レデーミクストコンクリート工場における 骨材置場の一例
材置場の 1 例であるが, 骨材は粒径別に貯蔵されている. 図 2 はミキシングプラントの 1 例であるが，粗骨材はも ちろえ細骨材も粗砂と細砂とに分けて取り扱らことが示

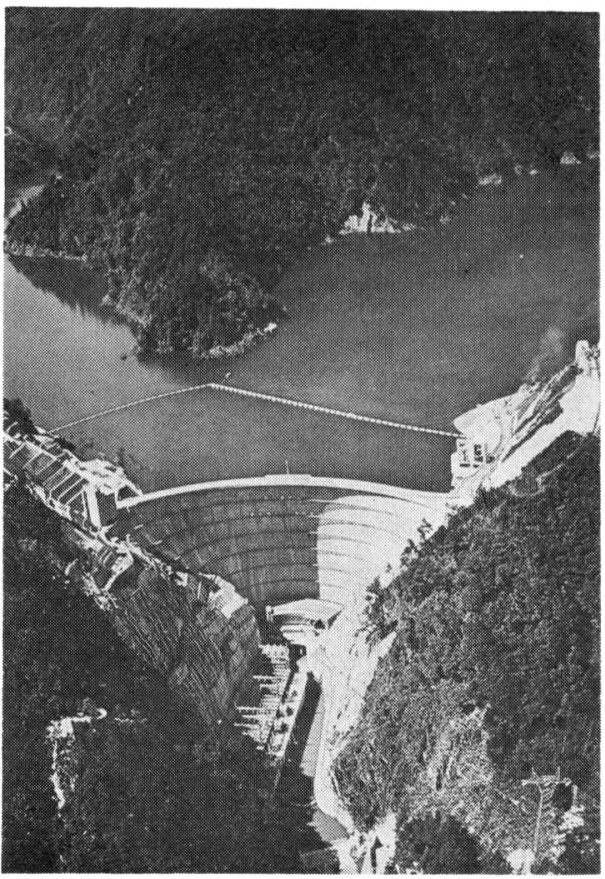

写真 2 東京電力会社奈川渡アーチダム (高さ $155 \mathrm{~m}$, コンクリート量 $660000 \mathrm{~m}^{3}$ )

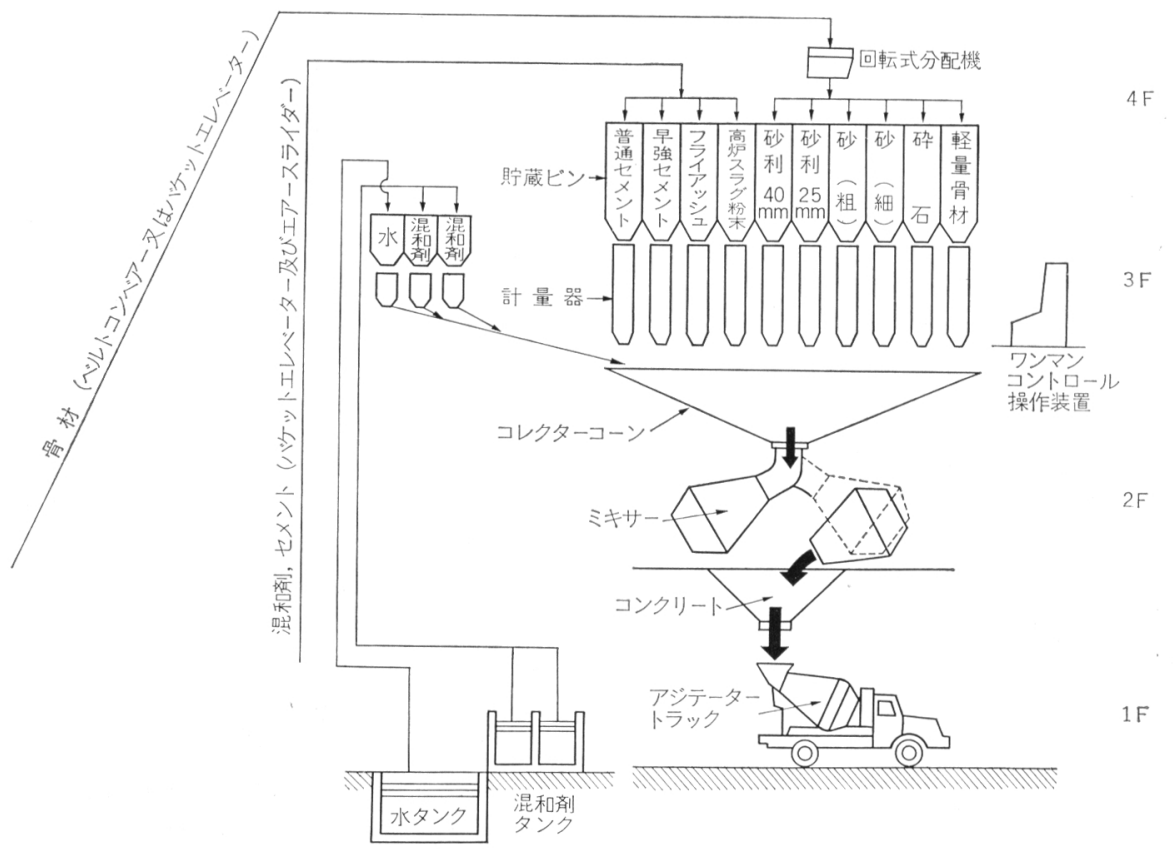

図 2 レデーミクストコンクリート工場におけるミクシングプラントの一例 
されている.

コンクリート大ダムの工事現場では, 細骨材の粒度を 特に入念に管理している. 例えば東京電力の奈川渡ダム (アーチダム, 高さ $155 \mathrm{~m}$, コンクリート量 $660000 \mathrm{~m}^{3}$, 写真 2 参照）の工事現場では粗・細骨材とも河川産のも のを使用したが，玉石や砂利をクラッシャーで破砕し， ふるい分け, 粗骨材を $150 \sim 80 \mathrm{~mm} \cdot 80 \sim 40 \mathrm{~mm} \cdot 40 \sim 20$ $\mathrm{mm} \cdot 20 \sim 5 \mathrm{~mm}$ の 4 種に区分すると共に，河川砂から 5 〜 $2.5 \mathrm{~mm}$ の粒の一部を除去しこれをロッドミルで破砕 して粒度調整に使用し所定の粒度の細骨材に仕上げたの である. 図 3 は，この骨材プラントのフローシートであ る. 表 1 は細骨材の粒度の試験結果であるが，良好な均 等性が得られたことが示されている9).

前記の例は原料の川砂が $2.5 \mathrm{~mm}$ 以上の部分を除いて は粒度が比較的に均等であつたので，図 3 に示すよらな 装置で好結果が得られたのである. 他のダムにおいて, 細骨材をまず粗・中・細の 3 種に分けて集積したのち, これらの 3 部分を所定の粒度の細骨材が得られるように 配合し好成績を挙げた例もある.な拈 $5 \mathrm{~mm}$ 以下を 6 種 に分け，これらを再配合し粒度の均等性を確保した例も ある.この場合, 細粒部分のふるい分けは不可能なので, 上昇水流中に粒子を懸垂させることにより粒径別に分級 した(この種の装置をジェットサイザーと呼んでいる). 上昇流速を相違させたポケットを順次に配置しておいて
細骨材を流せば，各ポケット中において懸垂状態に保た れる粒子の粒径は異なるので分級が可能なのである（流 速が大さい程大粒のものが懸垂され，小粒はオーバーフ ローして次のポケットに流される) ${ }^{10)}$.

アメリカコンクリート学会のシンポジウムでコンクリ 一トの均等性が論題となつたとき, “我々は骨材の粒度を 十分に管理しその均等性には確信を持つている.それに もかかわらずュンクリートの品質がばらつく最大の原因 はセメントの品質の変動である”と論じ, “あえてセメン トエンジニアーにチャレンジする”と大見得を切つたダ ムエンジニアーもあつたとのことである. 粒度の均等化 に情熱を傾けているコンクリート技術者は, 内外ともに 少なくない，前記の諸例は高炉スラグ細骨材の場合にも 参考となるものであろう。

(3) 高炉スラグ細骨材の粒度の区分について

高炉スラグ細骨材を製造する場合，単一粒度のものだ けを生産するか又は粗粒・中粒・細粒等に分類しそれぞ れの粒度のものを生産するかは，簡単には定められない 問題である.コンクリート工事に最も適した粒度は，部 材の種類並びに寸法・鉄筋の配置・コンクリートの配合· 締め固め装置・等によつて相違し, 一般に単位セメント 量が大きい場合には粗い粒度が適当であり小さい場合に は細かい粒度が望ましい. 従つて使用者としては, 複数 の粒度のものの中から適当な粒度を選択することを望む
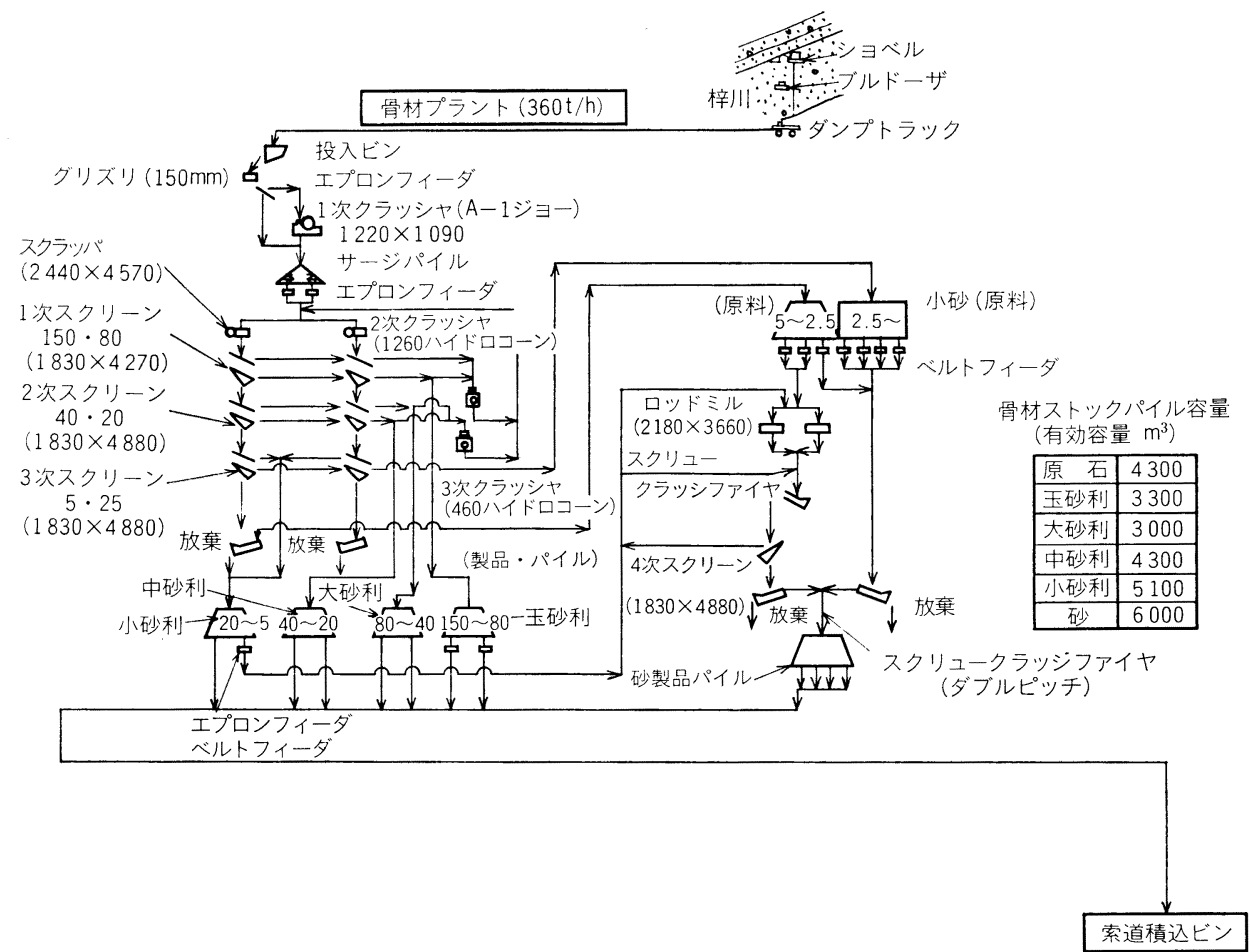

図 3 梓川水力開発工事における骨材プラントのフローシート 
表 1 細骨材粒度の管理試験結果

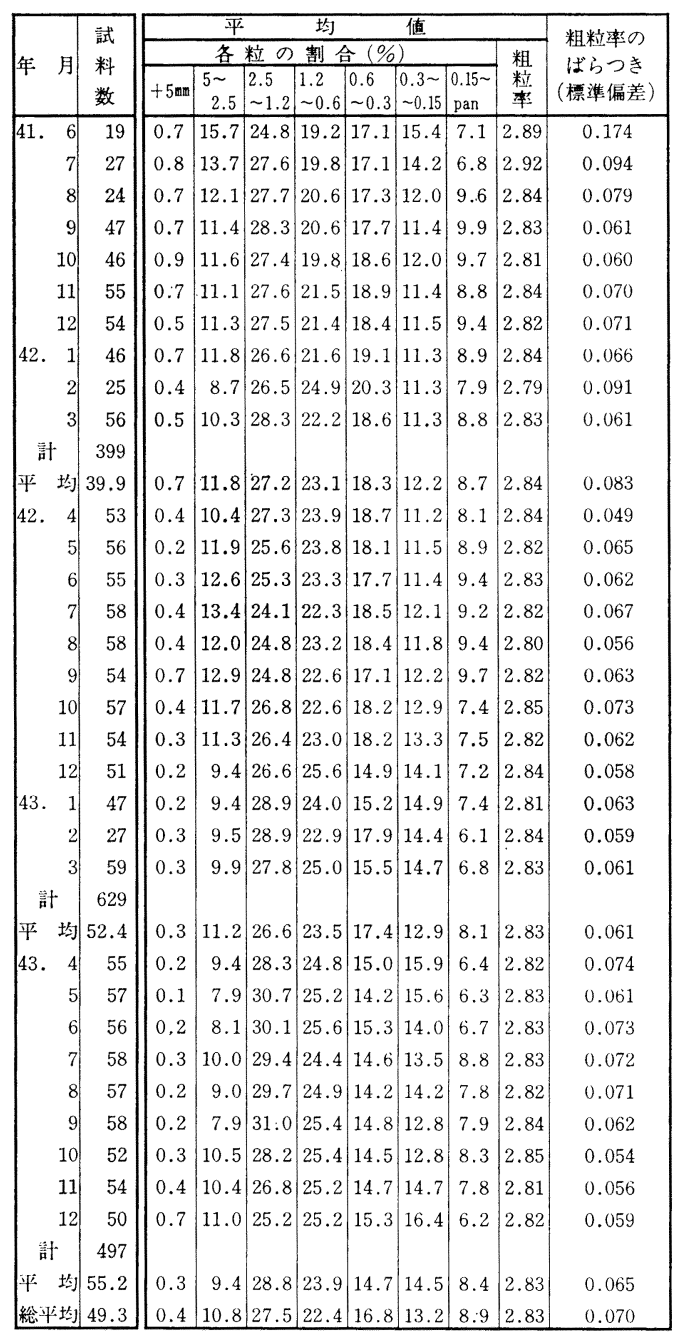

のは当然であつて，単一粒度だけを生産するのは，この 新製品の発展を阻害することにもなるであろら.

我がコンクリート界の最も大きな問題点は細骨材の欠 乏であつて，特に近畿・中国·四国・九州等の地域では 川砂はほとんど枯渴状態にあり，やむを得ず海砂を代用 している現状である. 海砂の第 1 の難点は塩分であり, これを無害な程度に洗つて使うことになるが，更に粒が 細かいといら短所がある. 従つて高炉スラグ細骨材と併 用し，粒度を改善することが望まれるが，この場合には 粗粒の高炉スラグ細骨材を用いなければならないのであ る.

高炉スラグから細骨材を造る場合，大小粒が適当に混 合されるように破砕することが多いが，これはェネルギ を必要とする上に，破砕した粒は角張るのでュンクリー トのワーカビリチーの点からは適当でない. 特に風砕は
粒が丸くて堅硬であるのが特徵であるので，これをあま り破砕することは，長所を遁減することにもなる．従つ て粒度を異にする $2 \sim 3$ 種のものを生産し, 使用者が手 持ちの細骨材に対する粒度改善として活用できるように しておく方が，製品の管理が容易となるばかりでなく省 エネルギの見地からも有利となるのである.

\section{5. コンクリート用混和材としての 高炉スラグの利用}

我が国のセメント生産量は膨大であつて年産 7000 万 $\mathrm{t}$ を超えており，この量はンビェトに次ぎ世界第 2 位の ものでありアメリカの生産量を凌駕している.アメリカ も日本もセメントの輸出量は少なく, 大半は国内消費に 充当されているので，この順位はそのままコンクリート 生産量の順位ともなつている. 従つて国土面積がアメリ カの $1 / 25$ にすぎない我が国が，アメリカよりも多量の コンクリートを生産し各方面に利用していることになる のであつて，良質の石灰石資源に恵まれている我が国の 著しい特徴である．この大量のセメントを製造するため の然料として，大部分の工場が重油を使用しているの で，七メントの節約はまさに省エネルギに直結するもの であつて極めて重要なことである.

急冷した高炉スラグを微粉砕したものは顕著な潜在水 硬性を有するので，これをセメント混和材として利用す る構想は古くからあり，高炉セメントA・B及び C 種と して市販されている. しかし使用されている量は意外に 少なく，3 種を合算しても全セメント量の $4 \%$ にすぎな い. その理由としては, 短期強度が弱いこと，低温時の 強度が弱いこと，等の高炬セメントの欠点も挙げられる が，高炉セメントは信頼度が低いといら使用者の観念が 主要な理由であるように思われる.

使用者のこの観念を短時日に改めることは不可能であ るし，高炉セメントの前記の欠点は粉末度の調整その他 によつてある程度まで補うことは可能である。それで私 は約 3 年以前から，セメントの適当量例えば 10〜15\%を 急冷高炉スラグ粉末で置き換えたものもポルトランドセ メントとして取り扱えるよらにJIS を改正することを， セメント協会や工業技術院の日本工業標準調査会の会合 で提唱してきた．これは高炉スラグの混和量だけセメン トクリンカーを節約し，省エネルギに寄与しようといら 構想であり，我が国が当面している最も重要な課題が石 油資源の節約であることを思えば，当然の提言である. フランスや西ドイッでも同様な趣旨で高炉スラグを活用 しているのである. 刻々と厳しくなりつつあるェネルギ 事情により，先般ポルトランドセメントのJIS が改正さ れ，七メント総量の $5 \%$ 以下の高炋スラグその他の混和 材の混和が認められた. 混和量は提案より削減されたが 省エネルギのスタートとして喜ばしい。

高炉スラグの粉末は，コンクリートの混和材としても 


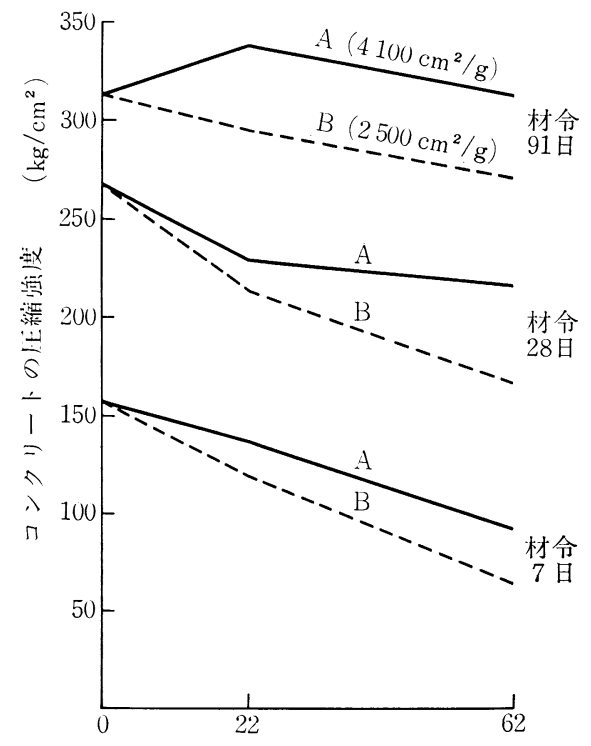

スラグによるセメントの置換え率（\%)

図 4 A (比表面積 $4100 \mathrm{~cm}^{2} / \mathrm{g}$ ), B (比表面 積 $\left.2500 \mathrm{~cm}^{2} / \mathrm{g}\right) 2$ 種の高炉スラグ粉末 を用いたコンクリートの圧縮強度

$\left(21^{\circ} \mathrm{C}\right.$ の水中養生)

使用できる，セメントの適当量を高炉スラグで置き換え たコンクリートは, 短期材令に拈ける強度は弱くなるが, 養生状態がよい場合には，長期材令においては高炉スラ グを用いないコンクリートより強くなる. 図 4 は 2 種類 のスラグ粉末を用いて普通ポルトランドセメントを置き 換えたコンクリートの強度を試験した一例であるが， 比表面積が $4100 \mathrm{~cm}^{2} / \mathrm{g}$ のスラグ $\mathrm{A}$ の場合にはセメント の $62 \%$ を置き換えても材令 91 日ではスラグを用いない コンクリートより強くなり， $2500 \mathrm{~cm}^{2} / \mathrm{g}$ の粗スラグ $\mathrm{B}$ の場合でも $22 \%$ の置き換えならば 91 日の強度はスラグ を用いないものと大差ないことが示されている4).

コンクリートの混和材として用いる場合には，セメン ト及び高炉スラグの化学成分並びに粉末度, コンクリー 卜の配合, 部材の種類及び寸法, 養生状態, 等に応じて セメントの置き換え率は使用者が適当に定めるので，ス ラグの使用量も前記のセメントの場合より多量となるの で一層の省エネルギが期待できるのである.

\section{6. 結 び}

土木·建築両分野のコンクリート研究者と鉄鋼分野の 専門家との協力によりこの数年間に実施された高炉スラ
グに関する広範囲の調査研究の結果，現在製造されてい る高炉スラグは工業副生品の域を脱し，粗・細骨材並び にセメント・コンクリート混和材として活用できる貴重 なコンクリート材料となり得ることが実証された。 これ は，近年に拈ける各製鉄所のスラグ関係諸施設の新設並 びに整備によるものであるが，貴重な材料としての実を 挙げるため，所要の品質を持つ均等性の高い製品の供給 が可能となるよう諸設備の一層の改善が要望される.

高炉スラグをコンクリート材料として使用する方法 は，構造物の種類並びに規模·工期 ·気候 · 工事現場の 事情・工費等によつて相違するのが当然であるが，でき るだけ有効に使用することが望ましい．省エネルギのた めにはポルトランドセメントの混和材並びにコンクリー ト用混和材として活用するのが最も有効である。また骨 材として使用する場合には，急冷スラグ細骨材として用 い，各工事現場に括ける細骨材の粒度補整用に活用する のが合理的であると思われる。

\section{交献}

1 ）国分正㳙，小林一輔，山崎寞司，吉田弥智 : 高炉 スラグのコンクリート材料としての利用，土木学 会誌 Annual '76, 昭和 51 年

2) 土木学会 : 高炉スラグ砕石コンクリート設計施工 指針(案), 昭和 53 年 5 月

3 ) 土木学会 : 高炉スラグ砕石コンクリート設計施工 指針(案) 講習会資料, 昭和 53 年 5 月

4) 小玉克巳 : 高炉スラグのコンクリートへの利用に 関する研究，土木学会論文報告集に投稿中

5 ) 建材試験センターコンクリート用高炉スラグ骨材 標準化研究委員会：コンクリート用高炉スラグ砕 砂 JIS 原案, 昭和 52 年 3 月

6 ) 小林正几：高灿スラグ砕砂コンクリートの諸性質 に関する研究，高炉滓のコンクリート用骨材への 利用に係る試験および JIS 原案・設計施工指針作 成に関する調查研究報告, 建材試験センター, 昭 和 52 年 3 月

7 ) 日本鉄鋼連盟：昭和 52 年度建設省建設技術研究 補助金研究 コンクリート用水砕スラグ細骨材の 使用規準の作成に関する研究報告書, 昭和 53 年 3 月

8 ) 日本鉄鋼連盟スラグ資源化委員会 : 水砕砂の固結 に関する実験概要報告書, 昭和 54 年 4 月

9 ) 東京電力株式会社: 样川水力開発工事報告, 昭和 47 年 3 月

10) 日本建設機械化協会：日本建設機械要覧（1964 年版） p. 680 ジェットサイザ，昭和 39 年 5 月 